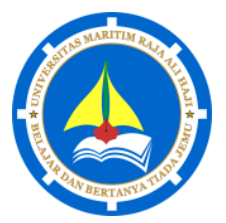

Jurnal Anugerah, 1(2) (2019)
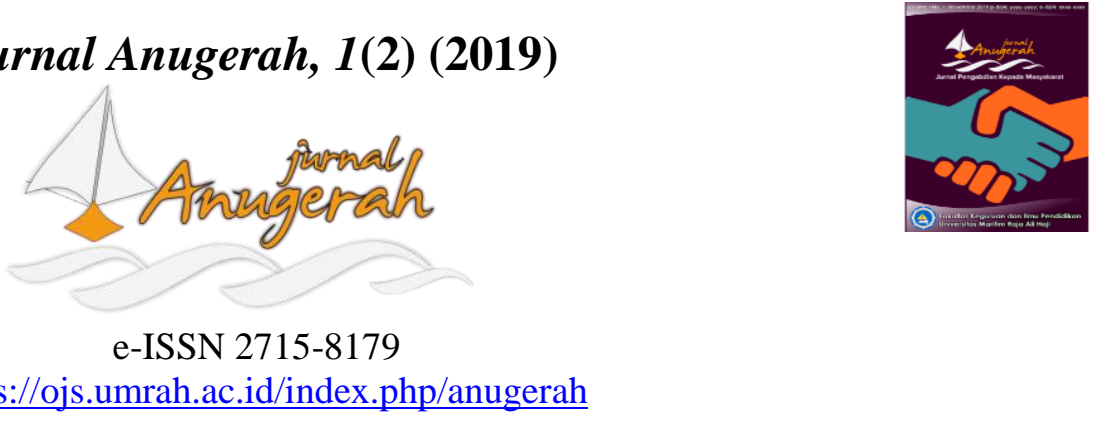

https://ojs.umrah.ac.id/index.php/anugerah

\title{
Pembinaan Penyelesaian Soal-soal Olimpiade Sains bagi Siswa SMP Negeri 4 Tanjungpinang
}

\author{
Dina Fitriyah $^{1 *}$, Dios Sarkity ${ }^{2}$, Mariyanti Elvi ${ }^{3}$, Metta Liana ${ }^{4}$ \\ 1, 2,3,4 Universitas Maritim Raja Ali Haji, Tanjungpinang, Provinsi Kepulauan Riau 29115, Indonesia \\ e-mail: *dinafitriyah@umrah.ac.id
}

Pengiriman: 2 Desember 2019; Diterima: 23 Desember 2019; Publikasi: 30 Desember 2019

DOI: https://doi.org/10.31629/anugerah.v1i2.1826

\begin{abstract}
Abstrak
Paradigma siswa saat ini yaitu cenderung beranggapan bahwa Sains adalah suatu ilmu pengetahuan yang sulit, abstrak dan tidak menarik. Sehingga berpengaruh terhadap minat siswa dalam mengikuti Olimpiade Sains Nasional (OSN). Selain itu siswa sudah terbiasa dengan permasalahan - permasalahan sains yang sederhana dan mudah saja, sehingga siswa tidak mampu menemukan solusi persoalan Sains yang rumit, khususnya soal - soal olimpiade. Hal ini menjadi perhatian khusus oleh Tim pengabdian Universitas Maritim Raja Ali Haji, sehingga dirasa perlu diadakannya pembinaan penyelesaian soalsoal olimpiade, sehingga siswa akan terbiasa dengan soal-soal bidang Sains, khususnya soal-soal bidang kimia level olimpiade. Kegiatan pengabdian yang dilakukan ini menggunakan metode kegiatan pendampingan dan pembinaan. Adapun peserta yang mengikuti pembinaan ini adalah siswa/i SMP Negeri 4 Tanjungpinang yang berjumlah 10 orang. Pembinaan dilakukan selama satu bulan (November 2019) dengan jadwal 2 (dua) kali seminggu yaitu pada hari Senin dan Sabtu. Berdasarkan hasil kegiatan pengabdian yang telah dilakukan dapat disimpulkan berdasarkan hasil tes kemampuan siswa bahwa kegiatan pembinaan penyelesaian soal-soal olimpiade Sains bidang Kimia pada topik materi kimia dan zat aditif dapat dikatakan berhasil. Hal ini dikarenakan $70 \%$ siswa yang mengikuti kegiatan pelatihan mendapatkan skor diatas 70 .
\end{abstract}

Kata kunci: olimpiade; pembinaan; soal-soal

\section{Abstract}

The current paradigm of students tends to assume that Science is a difficult, abstract and unattractive. This affects to interest of students in participating in the National Science Olympics (OSN). Students are already familiar with simple and easy science problems, they are not able to find solutions to complicated science problems, especially Olympic questions. This is a special concern by the University Maritim Raja Ali Haji Pkm team, so we feel the need to provide coaching to solve the Olympic questions, so students will get used to the questions in the field of Science, especially the questions on the chemistry of the Olympics level. The service activities carried out using the method of mentoring and coaching activities. The participants who took part in the training were 10 students from SMP Negeri 4 Tanjungpinang. Coaching is conducted for one month (November 2019) with a schedule of 2 (two) times a week, namely on Mondays and Saturdays. Based on the results of the devotion activities that have been carried out it can be concluded that Based on the results of the student's ability tests it is known that the activities of coaching the completion of the Science Olympiad questions in Chemistry on the topic of Chemical Materials and additives can be said to be successful. This is because $70 \%$ of students who participate in training activities get scores above 70

Keywords: olympiade; coaching; the questions 
JURNAL ANUGERAH, Desember 2019; I(2): 77-81

e-ISSN 2715-8179

\section{Pendahuluan}

Salah satu usaha Pemerintah dalam rangka peningkatan kualitas sumber daya manusia pada aspek pendidikan yaitu dengan mengadakan Olimpiade Sains Nasional (OSN) yang telah dirintis sejak tahun 2003. OSN dapat berperan sebagai wadah untuk meningkatkan keterampilan berpikir kritis siswa, mengembangkan daya nalar, kreativitas dan sportivitas siswa. Untuk jenjang SD dan SMP hanya ada dua bidang yang diikutsertakan dalam olimpiade sains ditingkat Kabupaten/Kota, nasional hingga ke tingkat Internasional yaitu matematika dan sains (BNSP, 2010).

Selama ini, siswa-siswa cenderung beranggapan bahwa sains adalah suatu ilmu pengetahuan yang sulit, abstrak dan tidak menarik, sehingga berpengaruh terhadap minat siswa untuk mengikuti olimpiade sains, banyak siswa yang tidak termotivasi untuk mengikuti OSN sains. Selain itu, siswa-siswa juga sudah terbiasa dengan permasalahan-permasalahan sains yang sederhana dan mudah saja, dan menyebabkan siswa tidak mampu menemukan solusi persoalan sains yang rumit, khususnya soal-soal olimpiade. Hal ini sejalan dengan pendapat Daane dalam Billy (2008) yang menyatakan bahwa fokus dari soal-soal non rutin pada level tinggi yaitu pada interpretasi dan mengorganisasi masalah. Soal level tinggi ini mengharuskan siswa untuk berpikir kritis, menambah pemahaman konsep siswa, mengembangkan penalaran, mengembangkan kemampuan berpikir abstrak dan mentransfer kemampuan Sains ke situasi yang tidak familiar.

Selain itu, Van Domelen (2009) juga mengatakan bahwa ciri dari masalah adalah membutuhkan daya pikir/nalar, memotivasi siswa untuk dapat memprediksi solusinya, serta cara untuk mendapatkan solusi tersebut tidaklah satu cara, dan harus dapat dibuktikan bahwa solusi yang didapat adalah benar/tepat. Suatu masalah dapat dipecahkan dengan berbagai langkah sesuai dengan konteks masalah tersebut. Heller \& Heler (2010) mengembangkan langkah-langkah pemecahan masalah sains yaitu memfokuskan permasalahan, menjabarkan aspek fisisnya, merencanakan pemecahan, menjalankan rencana pemecahan, dan mengevaluasi jawaban.

Permasalahan ini menjadi perhatian khusus oleh tim pengabdian Universitas Maritim Raja Ali Haji, sehingga perlu diadakannya pembinaan dengan memberikan bimbingan penyelesaian soal- soal yang setingkat dengan soal olimpiade, sehingga siswa akan terbiasa dengan soal-soal bidang sains, khususnya soal-soal bidang kimia dengan tingkat kesukaran yang sulit. Kegiatan pengabdian ini akan dilakukan di SMP Negeri 4 Tanjungpinang yang merupakan salah satu sekolah negeri di Tanjungpinang provinsi Kepulauan Riau yang berlokasi di Jalan Ahmad Yani. Selama ini, SMP Negeri 4 Tanjungpinang belum menunjukkan keberhasilan yang signifikan dalam bidang olimpiade sains, dibandingkan dengan sekolah lainnya yang telah melahirkan siswa maupun siswi yang berhasil meraih juara olimpiade sains baik nasional maupun internasional.

Berdasarkan hasil observasi awal yang dilakukan oleh tim pengabdian Universitas Maritim Raja Ali Haji, salah satu faktor rendahnya prestasi siswa/i SMP Negeri 4 Tanjungpinang dalam bidang olimpiade sains khususnya kimia adalah kurangnya proses pembimbingan soal-soal olimpiade yang dilakukan oleh guru terhadap siswa yang disebabkan karena kurangnya tenaga pendidik sebagai ahli dalam pembimbingan olimpiade sains siswa, khususnya bidang kimia. Proses pembimbingan hanya dilakukan oleh guru setiap akan mengikuti olimpiade saja, sehingga waktu pembimbingan kurang maksimal. Hal ini menyebabkan siswa tidak terbiasa dalam menyelesaikan soal-soal dengan tingkat kesukaran level olimpiade.

Kegiatan pembinaan penyelesaian soal-soal olimpiade ini dilakukan pada 10 orang siswa/i calon peserta olimpiade kelas Sains dari SMP Negeri 4 Tanjungpinang selama satu bulan dengan jadwal dua kali seminggu. Kegiatan ini lebih difokuskan pada pembinaan dalam menyelesaikan soal-soal olimpiade sains sehingga siswa diharapkan terbiasa dan mahir menyelesaikan soal-soal dengan taraf kesukaran pada level soal olimpiade.

Berdasarkan penjelasan di atas, maka diadakan suatu pelatihan bagi siswa untuk menyelesaikan soalsoal olimpiade sains bidang Kimia, terutama perlu adanya pembahasan-pembahasan soal olimpiade sains bidang Kimia sesuai dengan silabus materi olimpiade Sains. Kegiatan pengabdian ini merupakan salah satu 
bagian dari rangkaian pembinaan untuk mendapatkan siswa-siswi terbaik dari SMP Negeri 4 Tanjungpinang dengan harapan akan diikutsertakan pada olimpiade-olimpiade tingkat nasional.

\section{Metode}

Kegiatan pengabdian yang dilakukan ini menggunakan metode advokasi yang berupa kegiatan pendampingan dan pembinaan. Penyelesaian soal-soal olimpiade sains dilakukan dengan menggunakan strategi pemecahan masalah. Soal-soal yang dibahas merupakan soal-soal yang sesuai dengan silabus materi olimpiade sains serta pembahasan soal-soal olimpiade tahun sebelumnya. Tes yang berupa soal-soal ini merupakan instrumen pengumpul data untuk melihat keberhasilan kegiatan pembinaan soal-soal olimpiade yang dilakukan, dengan kriteria keberhasilan nilai siswa $>70$. Adapun peserta yang mengikuti pembinaan ini adalah siswa/i SMP Negeri 4 Tanjungpinang yang berjumlah 10 orang. Pembinaan dilakukan selama satu bulan (November 2019) dengan jadwal 2 (dua) kali seminggu yaitu pada hari Senin dan Sabtu.

\section{Hasil dan Pembahasan}

Acara pembukaan kegiatan pengabdian ini dilakukan pada hari Sabtu tanggal 02 November 2019 yang dihadiri oleh pihak Sekolah, tim pengabdian UMRAH dan siswa/i peserta pembinaan olimpiade yang berjumlah 20 orang, dengan rincian 10 orang dikelas matematika dan 10 orang di kelas sains. Kegiatan pengabdian yang berjudul "Pembinaan Penyelesaian Soal-Soal Olimpiade Sains Bidang Kimia pada Siswa SMP Negeri 4 Tanjungpinang" ini dilakukan diluar jam sekolah selama 2 kali seminggu yaitu hari Senin pukul 13.30 WIB dan pada hari Sabtu pukul 11.30 WIB.

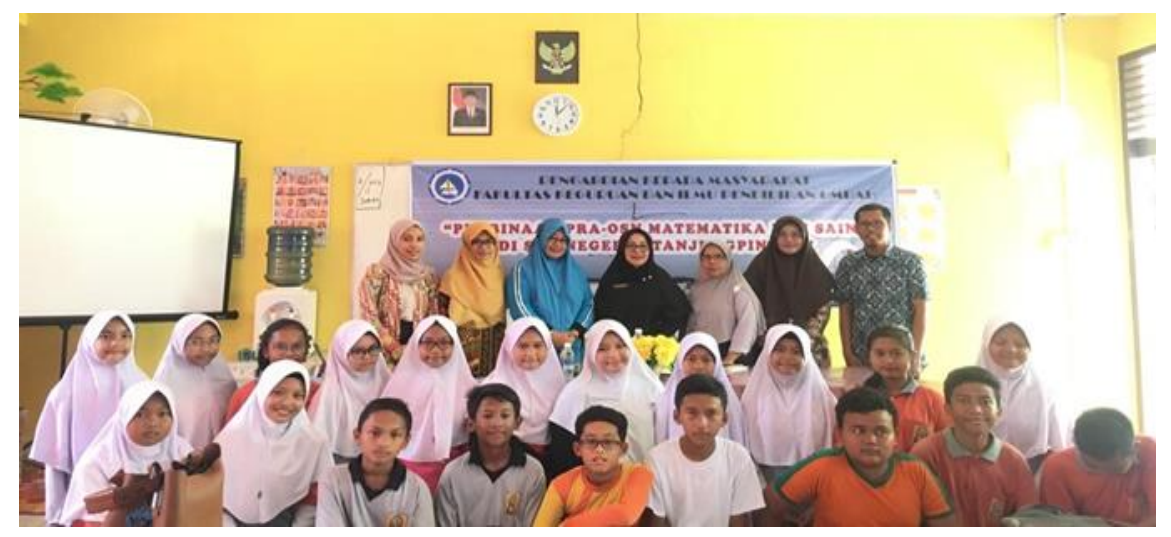

Gambar 1. Acara pembukaan Kegiatan pengabdian

Kegiatan pembinaan OSN di SMPN 4 Tanjungpinang diawali dengan persiapan mengumpulkan soalsoal olimpiade kimia dalam 3 tahun terakhir. Kemudian mereduksi soal-soal tersebut apakah masih relevan dengan kurikulum OSN yang dimuat pada buku panduan OSN. Kegiatan pembinaan OSN meliputi pengerjaan soal secara diskusi dan penjelasan oleh pembina terhadap materi-materi yang tidak dipahami siswa. Selajutnya evaluasi dilakukan untuk menilai kemajuan siswa dalam hal pemahaman dan keterampilan penyelesaian soal. 
JURNAL ANUGERAH, Desember 2019; I(2): 77-81

e-ISSN 2715-8179

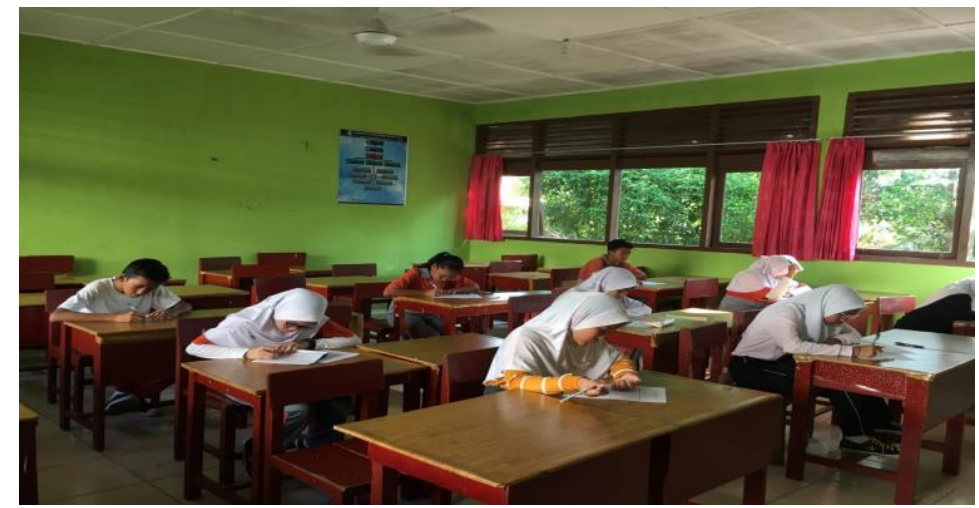

Gambar 2. Peserta Pembinaan OSN di SMP Negeri 4 Tanjungpinang

Soal yang diberikan berupa sola pilihan berganda. Adapun beberapa contoh latihan soal sains bidang kimia adalah sebagai berikut :

4. Berikut ini adalah rumus struktur guanidin yang terdapat dalam urin dari hasil metabolisme protein:

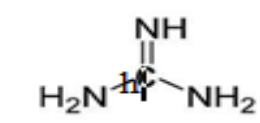

Persen massa nitrogen dalam guadinin adalah...
a. $77,78 \%$
b. $73,33 \%$
c. $71,19 \%$
d. $70,22 \%$

2. Senyawa trikloroetena banyak dipakai sebagai bahan pembersih. Di antara pereaksi berikut yang dapat bereaksi dengan trikloroetena menghasilkan produk khiral adalah
a. $\mathrm{H}_{2}$
b. $\mathrm{Br}_{2}$
c. $\mathrm{HCl}$
d. $\mathrm{NaOH}$

\section{Gambar 3. Contoh Soal Pembinaan OSN Bidang Kimia}

Pada awal kegiatan dilakukan pretest, kemudian dilanjutkan dengan pembinaan penyelesaian soal-soal olimpiade sains dan terakhir dilakukan posttest untuk melihat keberhasilan kegiatan pengabdian ini, maka dilakukan evaluasi terhadap hasil tes kemampuan siswa. Berdasarkan hasil tes kemampuan siswa dalam menyelesaikan soal-soal olimpiade pada topik materi kimia dan zat aditif dengan menggunakan strategi pemecahan masalah di atas, diketahui bahwa terdapat 7 siswa yang mendapat skor diatas 70 atau persentase banyak siswa yang mendapatkan skor 70 adalah $70 \%$. Hal ini menunjukkan terjadinya peningkatan kemampuan siswa, karena pada nilai evaluasi pretest, tidak ada satu siswapun yang memperoleh nilai 70 . Sehingga kegiatan pengabdian di SMP Negeri 4 Tanjupinang ini dapat dikatakan berhasil. Hasil pembinaan ini sejalan dengan hasil pembinaan OSN yang juga dilakukan oleh Wiyoko (2019) yang menyatakan bahwa pembinaan OSN di SD Negeri 102 Sei. Kerjan menunjukkan adanya peningkatan secara signifikan sebesar $40 \%$ untuk aspek pengetahuan, kemampuan menyelesaikan masalah sebesar $30 \%$ dan kemampuan menganalisis soal sebesar $20 \%$.

Namun demikian, masih terdapat beberapa hambatan dalam kegiatan pengabdian ini. Hambatan tersebut adalah beberapa siswa yang mengikuti pembimbingan soal-soal olimpiade sains kimia masih belum mendapatkan beberapa konsep yang harus dikuasai. Sebagai contoh, siswa kelas VII belum mendapatkan konsep penggolongan materi dan perhitungan kadar unsur dalam senyawa. Sehingga tim pengabdian UMRAH memberikan masukan bagi guru pengajar di SMP Negeri 4 Tanjungpinang adalah memberikan bekal terlebih dahulu secara mendalam kepada siswa khususnya siswa kelas VII yang akan mengikuti olimpiade berkaitan 
dengan konsep-konsep sains kimia yang harus dipelajari siswa. Hal ini agar siswa memiliki pengetahuan lebih berkaitan dengan konsep-konsep yang akan dibahas.

\section{Kesimpulan}

Berdasarkan hasil kegiatan pengabdian yang telah dilakukan dapat disimpulkan bahwa Berdasarkan hasil tes kemampuan siswa diketahui bahwa kegiatan pembinaan penyelesaian soal-soal olimpiade sains bidang kimia pada topik materi kimia dan zat aditif dapat dikatakan berhasil. Hal ini dikarenakan 70\% siswa yang mengikuti kegiatan pelatihan mendapatkan skor diatas 70 .

\section{Saran}

Saran yang dapat diberikan pada pelaksanaan kegiatan Pengabdian serupa di masa yang akan datang adalah sebagai berikut:

1. Mengadakan kegiatan pelatihan yang sama tetapi targetnya adalah guru-guru IPA yang menjadi pembina OSN se-Tanjungpinang.

2. Agar guru pengajar di SMP Negeri 4 Tanjungpinang sudah memberikan bekal terlebih dahulu kepada siswa khususnya siswa kelas VII yang akan mengikuti olimpiade berkaitan dengan konsep-konsep Sains Kimia yang biasanya di ujikan dalam OSN sehingga pada saat pembinaan penyelesaian soal-soal, siswa sudah memiliki konsep dasar.

\section{Ucapan Terima Kasih}

Tim Pengabdian UMRAH mengucapkan terima kasih kepada LP3M UMRAH yang telah memberikan dukungan demi terlaksananya kegiatan pengabdian ini. Selanjutnya, Tim Pengabdian UMRAH mengucapkan terima kasih kepada pihak SMP Negeri 4 Tanjungpinang yang telah memfasilitasi terlaksananya kegiatan pengabdian ini.

\section{Referensi}

Billy. (2008). Pengembangan Soal Matematika Non Rutin di SMA Xaverius 4 Palembang.Tesis. Jurusan Pendidikan Matematika Pascasarjana UNSRI.

BNSP. (2010). Pengembangan Paradigma Pendidikan Nasional Abad 21. Retrieved from http://www.bsnpindonesia.org/id/wp-content/uploads/2012/04/Laporan-BSNP-2010.pdf

Heller \& Heler. (2010). Problem Solving Labs, in Cooperative Group Problem Solving in Physics, Research Report, University Minnesota..

Solaz-Portolés, J.J., dan Lopez, V.S. (2007). Cognitive variables in science problem solving: a review of research. Journal Of Physics Teacher Education (JPTEO). 4(2).

Van Domelen, D. (2009). Problem-Solving Strategies: Mapping and Prescriptive Methods.

Department of Physics, The Ohio State University, Columbus, Ohi

Wiyoko, Tri. (2019).Peningkatan kompetensi siswa melalui pembinaan Olimpiade Sains (OSN). Jurnal Warta Lembaga Pengabdian Pada Masyarakat.Vol.22(2) September 2019 